Viso - Cadernos de estética aplicada Revista eletrônica de estética

ISSN 1981-4062

No 19, jul-dez/2016

http://www.revistaviso.com.br/
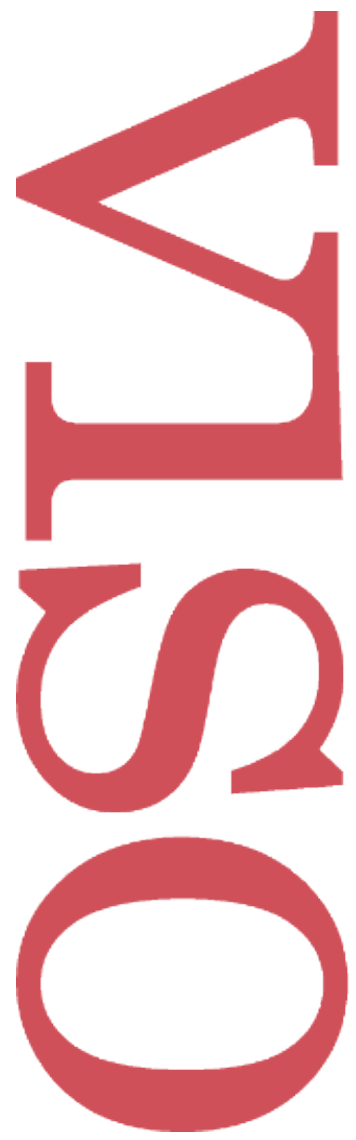

\title{
Adorno contra Heidegger: ontologia coercitiva da obra de arte Fernando Barros
}

Universidade Federal do Ceará (UFC) 


\section{RESUMO}

Adorno contra Heidegger: ontologia coercitiva da obra de arte

O propósito geral do texto que se segue é analisar, a partir das interpretações de Adorno e Heidegger, o modo como concebem a ideia de arte e, em especial, o papel que a ontologia exerce em tal contexto. Ao passar em revista os pontos divergentes dessas duas visões acerca da atividade artística, torna-se possível avaliar o sentido e o alcance de seus respectivos projetos filosóficos.

Palavras-chave: Adorno - Heidegger - obra de arte - ontologia - música - linguagem

\section{ABSTRACT}

\section{Adorno contra Heidegger: Coercitive Ontology of the Work of Art}

Considering the interpretations given by Adorno and Heidegger, the present text aims at analyzing how these two authors conceived the idea of art, and specially the role of ontology within this context. By scrutinizing the different points introduced by both views on artistic activity, it becomes possible to evaluate the meaning and the range of their philosophical projects.

Keywords: Adorno - Heidegger - work of art - ontology - music - language 


\section{BARROS, F. "Adorno contra Heidegger: ontologia coercitiva da obra de arte". In: Viso: Cadernos de estética aplicada, v. X, n. 19 (jul-dez/2016), pp. 29-47.}

DOI: 10.22409/1981-4062/v19i/228

Aprovado: 11.10.2016. Publicado: 28.12.2016.

(C) 2016 Fernando Barros. Esse documento é distribuído nos termos da licença Creative Commons Atribuição-NãoComercial 4.0 Internacional (CC-BY-NC), que permite, exceto para fins comerciais, copiar e redistribuir o material em qualquer formato ou meio, bem como remixá-lo, transformá-lo ou criar a partir dele, desde que seja dado o devido crédito e indicada a licença sob a qual ele foi originalmente publicado.

Licença: http://creativecommons.org/licenses/by-nc/4.0/deed.pt BR

Accepted: 11.10.2016. Published: 28.12.2016.

(C) 2016 Fernando Barros. This document is distributed under the terms of a Creative Commons Attribution-NonCommercial 4.0 International license (CC-BY-NC) which allows, except for commercial purposes, to copy and redistribute the material in any medium or format and to remix, transform, and build upon the material, provided the original work is properly cited and states its license.

License: http://creativecommons.org/licenses/by-nc/4.0/ 
O significado do termo "contra", que consta de nosso título, poderia ser açodadamente reduzido a uma perspectiva disruptivo-negativa e requer, à laia de introdução, uma pequena glosa. Com ele, não se pretende expressar, pela mera contrariedade, uma oposição dicotomicamente imantada - no sentido de um ímã que, vindo a se romper, sempre há de reproduzir as extremidades opostas. Tampouco se trata, no que se segue, de cotejar dois horizontes hermenêuticos a partir da suposta superioridade de um frente ao outro. A acepção dominante é a jurídica, aquela que costumamos ver, em autos e processos, como simples demanda e exposição de peças - "fulano contra sicrano", dirse-ia. Até porque, a julgar pelo embate travado entre os dois pensadores em questão, seria possível afirmar, quiçá, uma espécie de incomensurabilidade entre ambos. Adorno, dizia Heidegger, "é sociólogo, e não filósofo". ${ }^{1} \mathrm{E}$, sem deixar por menos, o primeiro também não hesitava em desmascarar o pesado tronco cognitivo que, a seu ver, brotava da clareira heideggeriana: "O dogmatismo torna-se para ele [Heidegger], em contraposição à tradição da crítica ao dogmatismo, a sabedoria mais elevada". ${ }^{2}$ Embalado por essa impermeabilidade, alguém bem que poderia, aliás, endossar os proferimentos heideggerianos sem dar a mínima atenção à crítica adorniana - e viceversa. Mas, se não cabe apenas marcar a discrepância entre pólos inconciliáveis, tratase menos ainda de dar ensejo, a seguir, à inócua neutralidade. Daí, essa ressalva inicial: se o presente texto terminar por se mostrar anti-heideggeriano, cumpre frisar que o prefixo "anti" terá um cunho acareativo, tencionando colocar Adorno "diante" de Heidegger, e não "no lugar" deste último. Em verdade, guardadas as devidas diferenças, poderia valer, aqui, a advertência que o próprio Adorno fizera, não sem uma pitada de sal, numa de suas conferências sobre ontologia: "Vocês teriam mal compreendido por completo minha conferência, se agora voltassem para casa e relatassem: 'pois é, o Adorno disse que Heidegger é um trapaceiro.' Digo isso quase que do mesmo modo que Nietzsche teria dito que Wagner é um trapaceiro". ${ }^{3}$

Salta aos olhos de quem lê os escritos seminais de Heidegger que neles a palavra ontologia adquire uma significação sui generis. Quando dela se serve, não reproduz os habituais inventários ontológicos, que se fiam em sistemas de categorias. Fatores de ordenação tais como, por exemplo, substância e acidente, subsistência e inerência, gênero e diferença designariam, no seu entender, apenas características singulares dos entes existentes, caracteres objetuais e periféricos, e não seu fundamento originário. Tampouco procura tornar operatória uma distinção conceitual entre entidades materiais e imateriais, no intuito de separar, a partir de uma dimensão suprassensível, objetos psíquicos de objetos abstratos - as ditas entidades intelectuais (ideias, números etc.) seriam, também elas, entidades ônticas desde a raiz. Empregando o termo em seu sentido vazio e desonerado de suas funções descritivas, Heidegger concebe a ontologia, como ele próprio dirá, "com a única pretensão de pensar qualquer questionamento e investigação dirigidos para o ser enquanto tal". ${ }^{4}$ Mais do que uma possível resposta à pergunta pelo modo de ser daquilo que é, a expressão diria respeito, no limite, à 
possibilidade do próprio perguntar, da oportunidade previamente dada por todo conhecimento ontológico. "Esta possibilidade de ser é uma possibilidade de ser concreta", escreve Heidegger, "portanto, a posição prévia não é nada que possa ser escolhido por algum capricho meu". ${ }^{5}$ A possibilidade de ser seria factível por ser a condição mesma da facticidade. Não há botânica antes das plantas, poder-se-ia dizer, sendo que é no mesmo instante que o factual e sua interpretação se tornariam possíveis, razão pela qual a ontologia heideggeriana não se quer dedutiva, mas primária num sentido ímpar:

Se chamarmos [...] a facticidade como a 'objetualidade' da hermenêutica (como as plantas são objetualidade da botânica), diremos que esta, a hermenêutica, encontra-se em sua própria objetualidade (ou seja, como se as plantas, o que são e como são, fossem a botânica). ${ }^{6}$

A despeito de sua constante preocupação com o cerne ontológico da "realidade", os filósofos, sempre consumidos pela chamada sedutora da presença [Vorhandenheit] dos objetos diante de seus olhos, jamais teriam voltado os holofotes para o irremissível grau zero de suas hipóteses de interpretação da história e da natureza, ignorando ou tomando por certa a condição prévia de compreensibilidade da possibilidade mais própria das indefinidas possibilidades de ser. Sempre à deriva nas pesquisas ontológicas tradicionais, a questão do ser teria perdido sua precedência - para Heidegger, necessária - frente aos demais domínios, motivo pelo qual o não-pertencimento a essa tradição converte-se, a bem dizer, na insígnia do saber que a ontologia fundamental conta inaugurar. Recusa que ganha relevo em passagens tais como, por exemplo:

Toda ontologia, por rico e firmemente articulado que seja o sistema de categorias à sua disposição, no fundo permanece cega e se desvia de sua intenção mais-própria, se antes não elucidou suficientemente o sentido de ser e não concebeu essa elucidação como sua tarefa-fundamental. ${ }^{7}$

Não é nem de longe inútil recorrer, como guia de leitura, aos comentários do próprio Adorno à introdução de Ser e tempo e, em especial, aos pressupostos teóricoespeculativos de tal "tarefa-fundamental". A esta subjaz a pretensão de que, em relação às ontologias específicas, haveria ainda uma pergunta mais visceral e ulterior, da qual dependeriam, inclusive, as demais investigações. A esse propósito, Adorno - que aqui se limita a seguir o fio de prumo do texto heideggeriano, consentindo, digamos, a ser guiado pelo autor - elucida dois níveis distintos da questão, dando a medida daquilo que seria filosoficamente primário em relação aos objetos temáticos de uma dada investigação positiva - no caso, das ciências históricas:

Há, em primeiro lugar, a questão ôntica. Trata-se, aqui, dito de modo muito simples, da questão imediata, ingenuamente científica [...] como, por exemplo: quais princípios básicos vigoram para a história em geral? O que significa história? [...] essas são chamadas por Heidegger, pois, de questões ontológicas no sentido ingênuo [...] Essas questões ontológicas, diz-nos ele, então, são decerto mais primordiais em relação à questão ôntica das ciências positivas. ${ }^{8}$ 
A questão ontológica adquire, pois, primazia frente às próprias coisas questionadas. Mas nem por isso a ideia reguladora das ciências históricas deveria ser um puro ser extramundano, desgarrado e perdido em paragens metafísicas, senão que o ser em relação a um ente transparentemente investigado; vinculado à ponderação ontológica fundamental, este último passaria a ser por ela afetado, deixando-se interpretar de uma maneira diferente face aos seus desdobramentos. Enganar-se-iam, por isso, os que pensassem que o impulso rumo à "efetiva realidade histórica ela mesma", fortalecida em vista e a serviço da precedência do ser frente ao ente, evocasse uma retroação à Idade de Ouro do ser, ou, quem sabe, às primícias da gênese humana. Isso porque, aqui, anterior não seria sinônimo de original, mas de "mais próximo" a si mesmo. Sobre a defesa de tal originariedade, Adorno comenta:

Agora, neste ponto, Heidegger e todo heideggeriano teria uma extrema reação alérgica, respondendo-nos com virulência que o sentido de primordial não equivale àquilo que é genética ou temporalmente anterior, senão que o mais primordial é justamente o que é ontologicamente mais primordial, isto é, aquilo que se acha bem mais próximo de tal enigmático e insólito ser, mais imediato em relação a este do que tudo o mais. ${ }^{10}$

Isto apenas para indicar que, segundo Heidegger, a teoria da história não poderia ser objeto do conhecimento histórico, se este último não se sentisse à altura de questionarse a si próprio. Ou, noutros termos, a historicidade seria a condição mesma para analisar o ente histórico - e não o contrário. Atendo-se aos "fatos", mas sem colocar em questão seus pressupostos totalizantes, as ciências positivas seriam, a despeito de seus métodos pretensamente objetivos, abstratas num duplo sentido, mostrando-se tributárias de abstrações feitas a partir da abstração do próprio ser.

Ciente, porém, de que sua leitura resulta, também ela, de uma dada avaliação do ente histórico, Adorno não se limita a refazer os movimentos internos do texto heideggeriano. Se não o remete a uma causa exterior, nem por isso deixa de apontar para onde ele remete, indicando a que vem e o que significa. Quando nos lembra que, para Heidegger, todo domínio do conhecimento deve questionar suas próprias constituição fundamentais, pondo-se a si mesmo à prova, acredita ser possível ler e interpretar a ontologia fundamental, também ela, sob tal ótica. E, de saída, elucida o que julga ser uma espécie de entimema escondido, presente na distinção entre a qualificação daquilo que se almeja explicar e a originariedade do ser absolutamente primeiro e verdadeiro. A própria precedência do ser face ao ente - tema a ser, senão definido, ao menos explicado - já estaria previamente dado na ideia mesma de originariedade. Nesse sentido, Adorno escreve:

Há, pois, num ponto central dessa filosofia, uma petitio principii; pressupõe-se, como algo já existente no conceito de originariedade, aquilo mesmo que tal filosofia tem de demonstrar, isto é, a antecedência do ser em relação às suas regiões individuais e tanto mais em relação aos entes particulares. ${ }^{11}$ 
É bem verdade que o próprio Heidegger anteviu tal objeção, precavendo-se de seus efeitos. Tanto é assim que dela se defende: "Na pergunta pelo sentido de ser não há um 'círculo na prova' mas, ao contrário, uma notável 'referência retroativa e projetiva' do perguntando (ser) ao perguntar como modus-de-ser de um ente". ${ }^{12} \mathrm{O}$ fato de não pretender derivar proposições a partir de uma fundamentação dedutiva, amparando-se, antes do mais, no modo como empreende a pergunta pelo ser, não eximiria o discurso heideggeriano de uma tarefa elucidativa mais transparente. Se Adorno imputa-lhe a falácia de instituir um princípio não demonstrado, é porque não comunga da ideia de que se possa determinar o ente em seu ser sem que seja "preciso para isso", como diz Heidegger, "que o conceito explícito do sentido do ser já deva estar disponível". ${ }^{13}$ Cabe frisar que a crítica não é feita em nome de nenhum suposto princípio de clareza e distinção e tampouco Adorno quer-se um pensador analítico clássico. Ao contrário, sua apreciação condenatória volta-se aos pensadores que se situam no ponto de vista do positivismo lógico - criticados, aliás, ironicamente, pela própria filosofia heideggeriana e à visão segundo a qual a reflexão filosófica seria, no fundo, uma tautologia. Quer dizer: "que a filosofia não seria, pois, capaz de nada mais a não ser explicitar aquilo que ela, ao mesmo tempo, já pressupõe”. ${ }^{14}$

Além de abreviar e nivelar os acontecimentos, reconciliando as contradições e igualando não-iguais, a maneira tautológica de pensar, baseada na mera não-contradição, ajudaria ainda a alimentar antigos preconceitos metafísicos. A começar com a crença de que haveria uma identidade estrutural à base e no início de todas as coisas. A própria originariedade do ser pressuposta pela ontologia fundamental prestaria testemunho da confiança naquilo que vem primeiro, presumindo que, a título de uma arché pré-reflexiva, a positividade e irredutibilidade do ser traria consigo algo qualitativamente mais verdadeiro, profundo e melhor do que todo ente que se revela através dele. Por isso, com a palavra "ser" Heidegger designaria "não propriamente o conceito de ser, senão que, antes de mais nada, o conceito de essência". ${ }^{15}$ Nada mais avesso, porém, ao pensamento dialético do que uma essência que pretende valer como verdadeira em função de sua gratuita prioridade, jactando-se em tomar-se como fundamento de todos fundamentos:

Acredito que a diferença efetivamente decisiva que existe entre o pensamento ontológico e fenomenológico, por um lado, e o pensamento dialético, por outro, deve ser buscado no fato de que esse primado do 'primeiro' [...] essa precedência do primeiro ou a redutibilidade ao que há de fundamental [...] não pode ser aceita. ${ }^{16}$

Não pode ser aceita, porque a ponderação dialética espera aplicar sua positividade na própria reflexão crítica, sem neutralizá-la mediante a força impalpável de um monismo essencialista - ainda que este se deixe travestir sob uma forma mais secularizada.

Como essência, o ser seria dissoluto, não se achando precisamente nem aqui nem acolá, mas em toda parte em que o ente o encontra e revela como fundamento. Seria, em sentido estrito, o nada em acepção negativa. O ser não é o ente, ou, como dirá 
Adorno: "A palavra ser não é o ser". ${ }^{17}$ É sobretudo por isso que a arte irá colocar-se, mais tarde, para Heidegger, como uma mediadora excepcional, capaz de pôr em foco a fulguração não conceitual do ser justamente por adquirir sentido sem que, para tanto, um conceito determinado tenha de estar, já, à mão. Dispensando a definição de algum objeto onticamente assinalado, o estudo ontológico - e não estético - da obra de arte articularia o construto artístico em seu ser, de sorte a mostrar que sua possibilidade já estaria pressuposta na ideia mesma de sua origem.

II.

Uma das primeiras coisas que se tornam patentes àquele que lê $A$ origem da obra de arte é que ali não toma a palavra o esteta no sentido habitual da alcunha. Aliás, poderse-ia afirmar que não há, em Heidegger, uma estética propriamente dita. Ele não elege, como ponto de partida, a pergunta "o que é arte?" e tampouco se dedica a analisar as supostas faculdades pelas quais a chamada beleza artística é ajuizada. É para marcar seu distanciamento das abordagens que tipificam a estética filosófica que escreve: "não perguntamos pela obra, mas antes, em parte, por uma coisa e, em parte, por um apetrecho [...] É a questionação da Estética [...] O que importa é [...] o facto de o caráter de obra [...] só se tornar mais próximo de nós, se pensamos o ser do ente". ${ }^{18} \mathrm{O}$ aspecto ôntico da obra não deve ser denegado, mas, se se trata de ir além das barreiras do que é óbvio, cumpre pensar tal aspecto a partir do caráter de obra da obra, o qual, segundo tal ponderação, afinar-se-ia com seu ser-obra, e não com o seu ser-coisa. O modo de questionar da estética seria ab ovo equivocado, porque a pergunta por aquilo que diferencia um objeto tido como arte de outro objeto que não é considerado como tal implicaria, desde logo, que já nos entendemos a respeito do que vem a ser um objeto artístico - como substância portadora de acidentes, por exemplo, ou, então, em termos do moderno subjetivismo, como multiplicidade dada às sensações. Ontológica no fundamento, a pergunta heideggeriana impõe-se, pois, no sentido de saber que sorte de coisas as obras de arte seriam, indagando pelo elemento "coisal" da coisa. Donde, a pergunta inicial: "O que é na verdade a coisa, na medida em que é uma coisa?" 19 Questão essa que, depois de desestabilizada a confiança na interpretação corrente de coisa, será apetrechada com o seguinte corolário: "A firmeza [das Ständige] de uma coisa, a consistência [Konsistenz] reside no fato de uma matéria se conjugar com uma forma". ${ }^{20}$

A matéria é, sempre, a matéria de algo, de alguma coisa. E, com efeito, parece impossível separar o caráter de coisa da obra de arte da materialidade ínsita, por assim dizer, à sua "coisidade." Afinal de contas, é a matéria que dá, às coisas, seu suporte sensível nuclear, base de tudo o que é colorido, duro ou sonoro. Como escreve Heidegger: "A escultura está na madeira. O quadro está na cor. A obra da palavra está no som da voz. A obra musical está no som". ${ }^{21}$ Mas, o esforço de Heidegger consiste justamente em tentar tirar a coisa de seu anonimato, mostrando que os meios tradicionais de compreender o suporte coisal da obra são insuficientes e que a noção de 
coisa como matéria enformada não pertence, em sentido preciso, à obra. Nesse trilho, somos fatalmente levados a revisitar a célebre distinção entre forma e matéria, a qual, em suas mais diferentes variedades, forneceria "o esquema conceptual por excelência para toda a estética e teoria da arte". ${ }^{22}$ Que tal esquema pode dar margens a ambiguidades, eis algo que o próprio Aristóteles já anunciava: "Ora, 'natureza' é ambígua no sentido de que pode referir-se tanto à matéria quanto à forma". ${ }^{23}$ Quente ou fria, água é sempre água, dir-se-ia. Daí a matéria $[H y ́ l e]$ de que as coisas são feitas não apresentar, sob tal ótica, o aspecto mais relevante da natureza. Sabei ver com profundidade, diria um metafísico, e vereis que é a forma [Eídos] que dá estrutura e determinação às coisas. Para enformar-se, a matéria teria de se deixar assimilar a uma ação finalizadora, ao acabamento de uma finalidade. E, "já que o fim é a forma, e todo o restante ocorre em vista do fim, é a forma que constitui a causa”. ${ }^{24}$ É bastante conhecida a estrutura geral que decorre dessa lógica produtiva - que faz o mármore, digamos, "virar" estátua: a forma efetua uma possibilidade que dormita na matéria e é, enquanto forma de algo, aquilo que é visto quando captamos o ser-criado pelo artista. Heidegger desconfia dessa visão de conjunto e não se contenta com a ideia de finalidade ou serventia em sua tentativa de caracterizar a gratuidade autárquica da obra de arte. Relegada à sua livre coisidade, a obra de arte não estaria conformada a nenhum fim específico, sendo que, "pela sua presença auto-suficiente, assemelha-se antes à mera coisa, dando-se em si própria e a nada forçada”. ${ }^{25}$

Assim colocado, o problema parece bastante simples: a criação artística teria sua finalidade em si mesma. O fabricar técnico-disciplinado, noutra coisa para além dele próprio. E, com isso, é Aristóteles que uma vez mais se faria ecoar: "Admite-se geralmente que toda arte e toda investigação, assim como toda ação e toda escolha, têm em mira um bem qualquer [...] Mas observa-se entre os fins uma certa diferença: alguns são atividades, outros são produtos distintos das atividades que os produzem". ${ }^{26} \mathrm{De}$ um lado, a atividade que se consuma e completa em seu próprio atuar; de outro, o fabricar guiado pela finalidade de seu produto, determinado pela realização prática. Aqui, a coisa por fazer. Lá, o que só vem a ser em sendo, o pleno "estar-em-obra". Heidegger, porém, é mais exigente. Pela ideia de ser-obra da obra de arte, ele conta suspender, ou, antes do mais, interrelacionar as determinações aristotélicas do agir e fabricar. No todo unido de forma e matéria que constitui o saber artístico, a obra feita dá-se no modo da ação. Diz-nos ele: "o todo unido da morphé e da hýle, a saber, o ergon é no modo de enérgeia." ${ }^{27}$ A criação artística "presente" no ser-criado, à diferença da fabricação técnica da manufatura, permaneceria atuante na obra mesmo que, depois, o artista se tornasse "indiferente em relação à obra, quase como um acesso para o surgimento da obra, acesso que a si próprio se anula na criação". ${ }^{28}$ Isso porque, na obra, a objetividade é fruto de uma vivência singular. E esta, por sua vez, converte-se em objetividade.

Por ser também um artesão, o artista é, não raro, reduzido à figura do técnico. A materialidade que se oferece à manufatura técnica pode, é claro, fazer parte do material artístico, mas não o contrário. Pois, por mais que a consistência material da obra nos 
induza a compreender sua efetividade como algo independente e anterior à obra - como a madeira, por exemplo, no caso de um entalhe -, cumpre frisar que o material artístico só se deixaria reconhecer, para Heidegger, a partir de seu ser-obra, e não de seu sercoisa. O caminho trilhado pelo artista "não é um caminho que leva à obra através da coisa, mas antes, ao invés, um caminho que leva à coisa através da obra" ${ }^{29}$, de sorte que, antes do trabalho sobre a obra, seu caminho não é ainda o caminho da criação. É precisamente para rechaçar os parâmetros da causalidade que insiste em enquadrar a atividade artística na atividade de um fazer instrumental, de um fabricar próprio à manufatura - no sentido de uma fabricação disciplinada e teleologicamente orientada que se dirá: "tékhne não significa nem manufatura, nem arte e, ainda menos, trabalho técnico no sentido actual [...] A palavra tékhne quer dizer muito mais um modo do saber. Saber quer dizer: ter visto, no sentido lato de ver". ${ }^{30}$

A criação artística, assim entendida, não seria propriamente um fazer, mas um agir singular, apto a tornar visível um aspecto do ente que, relegado a si, não se submeteria ao olhar. Nesse patamar reflexivo mais epifânico do que apofântico, não é qualquer essência, porém, que se daria a conhecer na apreensão do ente que se mostra enquanto tal. Para descrevê-la, convém lançar mão de um antigo vocábulo: "Verdade deve pensarse no sentido da essência do verdadeiro. Pensamo-la a partir da evocação da palavra dos gregos alétheia, que quer dizer a desocultação [Unverborgenheit] do ente". ${ }^{31}$ A noção de verdade haurida do termo alétheia, no sentido de não-encobrimento, é decerto bemvinda para pôr em cena o acontecimento descrito por Heidegger, porquanto, como desocultação do ente naquilo que ele é, a verdade artística assim designada pressupõe, em sentido lato, uma espécie de vidência por parte de quem a entrevê; o que, já de si, coaduna-se com a ideia, cara ao autor de Ser e tempo, de que a questão-do-ser implica "tornar transparente um ente"32; e também faz coro com o aceite de que o ser "tem o caráter de uma vista prévia" ${ }^{33}$ a ele dirigida. Em seu obrar projetante, a verdade do ente na obra de arte distingue-se, por sua subfiguração, da veracidade comumente atribuída ao dito discurso veraz - o qual não "vemos", mas "compreendemos"; o qual não se sujeita à figura, mas ao entendimento. Na obra, advém um desabrochar do ente como ele é, está em jogo um acontecer a ser experienciado, e não apenas inteligido, sendo que, para tornar plausível tal complemento vivencial, Heidegger detém-se na ponderação sobre o par de sapatos de uma camponesa retratado em "uma conhecida pintura de van Gogh, que pintou várias vezes calçado deste gênero" ${ }^{34}$ - trata-se, muito provavelmente, do quadro Um par de sapatos, feito pelo pintor holandês a partir de sapatos que comprara num mercado de pulgas parisiense e que o filósofo alemão pode ter visto, em março de 1930, em Amsterdã ${ }^{35}$ :

A camponesa no campo traz os sapatos. Só aqui eles são o que são. E tanto mais autenticamente o são, quanto menos a camponesa durante a lida pensa neles, ou olha para eles ou até mesmo os sente. Ela está de pé e anda com eles. [...] Neste processo de uso do apetrecho, o caráter instrumental de apetrecho deve realmente vir ao nosso encontro. ${ }^{36}$ 
Redirecionando os holofotes que convergiam para os conceitos dominantes da coisa, de sorte a apontá-los, então, na direção de aspectos mais recuados - caráter coisal e instrumental -, Heidegger tencionava nos sensificar para o caráter de obra da obra. Agora, abstraindo do próprio instrumento em sua utilização, conta fazer brotar, como que das entranhas da terra, algo que seria mais essencial ao apetrecho, nublado por sua serventia, a saber: sua confiabilidade [Verlässlichkeit]. A essa seríamos levados, não mediante a matéria enformada, senão que, para seguir o exemplo pictórico, por meio daquilo que talvez nos passasse desapercebido no andar discreto da camponesa em seu trabalho sobre o campo. Como, por exemplo, seu "temor pela segurança do pão, a silenciosa alegria de vencer uma vez mais a miséria". ${ }^{37} \mathrm{~A}$ bem dessa intuição congenial, cumpre enfatizar que, para a camponesa, seu calçado não serve apenas para ser calçado, senão que para participar do solo, de cuja aspereza as solas a protegem, mas de cuja fartura ela também usufrui, prestando testemunho de um vínculo umbilical com seu entorno. "Entorno", porque pouco importa, em verdade, o exato espaço físico em que tal acontecimento se dá; assim como o objeto não é, aqui, entrevisto apenas a partir de seu aspecto ôntico, tampouco o espaço é concebido somente a partir dos corpos, mas em relação aos acontecimentos que ele acolhe e aos seres vivos que, interagindo, terminam por constitui-lo. Vale para o mundo da camponesa, no limite, aquilo que o Heidegger tardio dirá sobre a relação entre arte e espaço: "O homem não é no espaço como um corpo [Körper]. O homem é no espaço, de modo que ele instala [einräumen] o espaço, sempre já instalou espaço [...] O homem permite o espaço como espaçante [Räumende]". ${ }^{38}$

O que há de mais intensivo nesse acontecimento anseia, segundo Heidegger, por uma consolidação específica, adquirindo o vértice de sua expressão na poesia. "A arte", diznos ele, "enquanto pôr-em-obra-da-verdade, é Poesia". ${ }^{39} \mathrm{E}$ há motivos bastantes para que tal palavra se ofereça à leitura em caixa alta, pois a letra maiúscula, aqui, serve para designar o sentido amplo de Dichtung, cuja densidade abrange, ao menos em sua acepção heideggeriana, o mundo instaurado por todas as modalidades artísticas. Vetores dadivosos de desocultação, estas últimas seriam, em sua plenitude, atividades fundamentalmente poéticas, na medida em que descerrariam, para nós, o mundo que nos dá abrigo e sentido. Daí, a cabal observação: "A Poesia é aqui pensada num sentido tão vasto e, ao mesmo tempo, numa união essencial tão íntima com a linguagem e a palavra que tem de permanecer em aberto se a arte, e mais propriamente em todos os seus modos [...] esgota a essência da Poesia". ${ }^{40}$ A linguagem não é essencialmente poética porque a poesia escrita e falada é, já de si, poetizadora. Mas, ao contrário: a Poesia ocorreria sobretudo na linguagem, porque esta seria a fiel depositária do dizer projetante pelo qual o ente se nos abriria como tal, acontecimento que, como escreve Heidegger, "faz ao mesmo tempo advir, enquanto tal, o indizível ao mundo". ${ }^{41} \mathrm{Em}$ sua estrita acepção, a poesia seria uma Poesia mais original, porque a linguagem seria capaz, como que por destinação, de trazer à configuração elementos aparentemente invisíveis, mas essenciais - dando à luz o ser que, de outro modo, permaneceria no limbo do ôntico. No fundo, o que se dá nas demais maneiras de poetar "já aconteceu, e 
inadvertidamente, na linguagem"; "A2 "A linguagem fala", lemos também numa célebre passagem, "o ser humano fala na medida em que corresponde à linguagem". ${ }^{43}$

Sem buscar refazer, aqui, outros passos da exposição heideggeriana - tarefa que suplantaria os limites, afinal de contas, estreitos deste nosso ensaio -, não seria fora de propósito problematizar a relação obra/produção a partir de tal panorama hermenêutico. É certo que de um texto poético - uma obra escrita, portanto - pode-se dizer que ele nos interpela das mais variadas formas, levando-nos a pensar que tem algo a nos "falar". Também não seria impossível asseverar que, em seus traços e formas estruturais - em sua Gestalt, dir-se-ia -, certas obras plásticas e arquitetônicas deixam ecoar um "gesto", qual uma marca ou intenção que o criador imprimiu à sua criação. Passando ao largo, aqui, da temática acerca do entrelaçamento entre os meios artísticos e das conflituosas recepções, num certo métier, de características nascidas de outras formas de arte, convém todavia perguntar: estaríamos tão seguros de tratarmos de algo "consistente", de uma "coisa" ou de um arcabouço sensível "confiável" quando consideramos, por exemplo, a música? Afinal de contas, qual aspecto "coisal" poderia, na música, oferecerse como obra de arte? As partituras? Suas execuções? Suportes de gravação? E não é sintomático o fato de Heidegger quase nunca explorar, em suas ponderações, justamente a arte dos sons?

Numa das raríssimas vezes em que cita nominalmente obras musicais, Heidegger referese à Sinfonia dos salmos e Perséfone de Stravinsky, afirmando que ambas seriam "música no mais elevado sentido da palavra; obras presenteadas pelas musas". ${ }^{44}$ Mas em relação a qual ordem de coisas tais obras seriam dependentes? Dizer que suas qualidades estariam para os nossos sentimentos assim como os atributos dos objetos estariam para as nossas sensações seria enquadrar a reflexão heideggeriana num subjetivismo que ela não comporta e tampouco endossa. "Muito mais próximo do que todas as sensações", escreve Heidegger a propósito, "estão, para nós, as próprias coisas. Ouvimos em casa a porta a bater e nunca ouvimos as sensações acústicas ou mesmo os meros ruídos". ${ }^{45}$ Mas, por não considerar a especificidade do material musical, tal visão revela-se questionável sob vários aspectos. Se o par de sapatos descrito por Heidegger pertence, não apenas ao mundo das "coisas", mas também, e sobretudo, ao mundo no sentido da physis, do brotar e nascer do campo "sobre o qual sopra um vento agreste" que estas se encontrariam, desde já, como que implantadas à maneira da natureza, acompanhadas por uma biofonia florestal cujos sons nos serviriam, para utilizar aqui a expressão de Bernie Krause, de "orquestra natural de caraoquê". ${ }^{47} \mathrm{Em}$ seu afã para desocultar o ser, o autor de $A$ origem da obra de arte teria, em verdade, ocultado o próprio ente da arte dos sons, abrindo mão da análise destes últimos em prol da análise ontológica. E, embalado por uma luta sem trégua contra a subjetividade, jamais se dedicaria a explicar as razões estéticas que o teriam levado, por exemplo, a detestar a música de Anton von Webern ${ }^{48}$, mas não mediria esforços, em contrapartida, para criticar 
o subjetivismo na música em geral - como aquele que detecta, por exemplo, na obra de Richard Wagner, cuja tentativa artística

tinha de falhar, não só por causa da predominância da música em relação às demais artes. Que a música pôde assumir tal primazia se deve, já, ao seu crescente posicionamento estético em relação à arte em geral: trata-se da concepção e apreciação da arte a partir do mero estado sentimental. ${ }^{49}$

Outra é a perspectiva esposada por Adorno. Sobre a já aludida Sinfonia dos salmos, dizia tratar-se de uma "missa negra" cuja mística negativa não deveria ser buscada nos sentimentos russos primordiais, senão que em sentimentos religiosos: "o atelier, aqui, é a capela, o cavalete, o altar e Paris 'vaut bien une messe' ['vale bem uma missa']". ${ }^{50} \mathrm{Se}$ assim escreve, é porque acredita que, na produção de sua obra, o compositor lida com um material sonoro que foi, ele mesmo, produzido culturalmente. Sua atividade compositiva é a atividade de um sujeito que opera sobre uma subjetividade que foi, aos poucos, objetivada sob a forma de sons. Como possibilidade historicamente préformada, o material musical não cai do céu, por assim dizer, senão que brota do movimento imanente de antigas formas de sonoridade, das quais os novos compositores se valem, mas, ao mesmo tempo, delas se afastam mediante saltos qualitativos. Por isso, dirá Adorno, "não se deve atribuir ao material sonoro em si [...] um direito ontológico próprio [...] As exigências impostas ao sujeito pelo material provêm antes do fato de que o próprio 'material' é espírito sedimentado, algo socialmente preformado pela consciência do homem". ${ }^{1}$

Questionável seria, também, a ideia de que o ato poético constitui o dizer essencial da desocultação dos entes. Presumir que, na linguagem, o ser humano se expõe a um suposto núcleo ontológico da realidade, ou, então, que lhe seria facultado acessar, pela poesia, uma abertura ao ser no sentido da ontologia fundamental requer pensar que algumas formas do discurso dizem algo sobre o próprio ser. Para Adorno, no entanto, isso estaria longe de ser evidente, referindo-se, antes do mais, a uma tendência à substancialização que parte da estrutura categorial da linguagem, ou, mais precisamente, da cópula:

A forma linguística que deve obter sua substancialidade no conceito de ser é a cópula. Esta nada é senão que pura e simplesmente o 'é' contido no juízo predicativo A é B [...] o conceito de ser refere-se, também ele, segundo sua origem e conforme sua legitimação, imediatamente à estrutura categorial da linguagem. ${ }^{52}$

Supor, porém, que tudo aquilo que é constitutivo para a linguagem tenha de ser igualmente constitutivo para as coisas implica aceitar que significados e entes se revestem tautologicamente com a mesma substância, de sorte que o ser seria, no fundo, aquilo que o conceito de ser significa. Não por acaso, Adorno dirá: "A ontologia de Heidegger é largamente fundada na doutrina do significado" ${ }^{53}$ Nesse sentido, a mais 
atenta crítica à ontologia da obra de arte - em especial, em sua forma musical - não poderá deixar de ser igualmente uma crítica à linguagem conceitual. Senão, vejamos.

III.

Que se tome, como ponto de convergência da crítica de Adorno, o primeiro parágrafo de seu "Fragmento sobre música e linguagem":

A música assemelha-se à linguagem. Expressões tais como idioma musical e tom musical não são metáforas. No entanto, a música não é linguagem. Sua semelhança com a linguagem aponta para o caminho da interioridade, mas também rumo ao vago. Quem toma a música literalmente como linguagem termina por se enganar. ${ }^{54}$

Deixamo-nos enganar, porque, segundo Adorno, o sentido que impomos por meio da música não é propriamente verbal ou linguístico, mas, ao mesmo tempo, na formulação "idioma musical", o falar não é apenas uma metáfora. Como sucessão temporal de sons articulados, o contínuo musical é mais do que mero som, sendo que sua semelhança com a linguagem adviria, pois, não somente do nexo organizado de relações acústicas, senão que de um perfilamento eloquente de suas vozes, motivo pelo qual "o gesto da música é tomado de empréstimo da voz que fala". ${ }^{55}$ Contudo, à diferença da linguagem discursiva, a eloquência à base dos construtos musicais não estaria apenas a serviço de funções representativas, mas de movimentos somáticos e pulsonais, cujas intenções intermitentes seriam, por assim dizer, mediatizadas por princípios compositivos artísticomiméticos. Mais do que uma garantia objetivante da expressão musical, tal mediação seria fruto de uma organização inventiva e autônoma, a qual, segundo o autor da Teoria estética, precisa "conformar-se sem plano, por assim dizer, a partir dos impulsos miméticos" ${ }^{56}$ Ora, dar determinação a estados pulsionais internos, no sentido de tornálos motivos musicais e formas elaboradas, não é o mesmo que representar e descrever atributos lógicos de objetos. A configuração reflexiva que mediatiza a imediatez do impulso mimético é decerto uma fabricação disciplinada e totalizante, mas haurida de uma opacidade que o conceito não comporta e, em rigor, mal pressente. Daí, uma outra instigante observação contida no fragmento:

Comparada à linguagem referencial, a música constitui, pois, uma linguagem de um tipo totalmente diferente. [...] O que ela diz se acha, naquilo mesmo que declara, a um só tempo determinado e velado. [...] É uma prece desmitologizada, livre da magia daquilo que sugestiona; trata-se da tentativa humana, por mais vã que seja, de nomear o próprio nome, e não de comunicar significações. ${ }^{57}$

Não se trata, em música, de sons e ruídos que deveriam ser semioticamente reconduzidos a significações antecipadamente instituídas, mas de formas que podem vir a assumir um sentido de acordo com a situação e configuração que adquirem ao se efetivarem, razão pela qual, no fragmento, Adorno conta nos remeter à esfera que designa a execução musical propriamente dita. "Música e linguagem", diz-nos ele, "carecem da interpretação em igual medida, mas de um modo totalmente diferente. 
Interpretar a linguagem significa: entender a linguagem; interpretar a música significa: fazer música". ${ }^{58} \mathrm{~A}$ música exigiria, pois, não uma decifração mediante palavras, mas uma abordagem sem muitos desvios, atenta ao fato de que a mediação que se dá entre o impulso mimético e seus reflexivos construtos musicais se desdobra segundo uma lógica distinta daquela que governa a linguagem referencial. Não por acaso, costuma-se buscar a marca distintiva entre música e linguagem no fato de a primeira desconhecer o conceito. No entanto, como dirá ainda Adorno:

[...] muito do que há nela [na música] se aproxima bastante dos 'conceitos primitivos' tratados pela teoria do conhecimento. Ela lança mão de siglas recorrentes. Estas foram cunhadas pela própria tonalidade. Se não amadureceu conceitos, esta última não obstante produziu vocábulos [...] acordes introduzidos constante e recorrentemente com função idêntica. ${ }^{59}$

Embora deixem entrever critérios de organização preteridos pela própria racionalidade, os signos musicais, pela recorrência e constância impostas pela tonalidade, passaram a fazer as vezes de "conceitos". Cuidando de si mesmas, por assim dizer, tais siglas recorrentes também estabeleceriam relações particulares, cedendo terreno, não raro, a especificações lítero-musicais. Tanto é assim que Adorno acrescentará: "a tradicional doutrina das formas musicais conhece a frase, o sintagma, o período, a pontuação; a interrogação e a exclamação, sendo que as orações subordinadas estão por todas as partes". ${ }^{60}$ Todavia, por conta do caráter prático-interpretativo dos construtos musicais, a identidade de tais "vocábulos" estaria na própria relação diferencial que estabelecem entre si, e não em algo por eles denotado. Sob tal perspectiva, poder-se-ia dizer que o processo de formalização musical encarna um princípio identitário que põe em questão o próprio ideal clássico de inteligibilidade, porque já se acharia eivado, de saída, daquilo que não é idêntico ao conceito. O problema todo, assevera Adorno - que aqui passa a criticar a música sob uma ótica imanente -, é que a invariância de tal processo "sedimentou-se tal como uma segunda natureza". ${ }^{61}$ Pelo uso frequente de suas fórmulas, a teoria musical esqueceu-se de sua própria arbitrariedade, assim como os conceitos, em filosofia, adquiriram vida própria, qual um feiticeiro que perdeu o controle sobre seus feitiços. Concedendo aos sons uma única função estrutural, neles gravada desde o despertar da tonalidade, considerou-os irrefletidamente como "naturais", sem data de fabricação ou validade. Tomando por certas as convenções de identidade e discrepância entre os signos sonoros, terminou por soterrar outros esquemas de concatenação, bem como outras possíveis técnicas compositivas. Com isso, acabou por incorporar, ironicamente, a invariabilidade e repetição mecânica que até então se imputava à natureza sonora "bruta", arvorando-se no único critério válido de criação musical. É justamente essa invariância irrefletida que, tal como se lê ainda no fragmento, "torna tão difícil à consciência o abandono da tonalidade". ${ }^{62}$

Após o reconhecimento da "naturalização" dos construtos culturais como fruto do esquecimento da organização instrumental das forças telúricas à base da animalidade humana, perde peso a tentativa de encontrar um sentido trans-histórico puro, o qual, 
dormitando numa temporalidade própria ao ser - numa "temporaneidade" [Temporalität] -, estaria para além da civilização. Sustentar que a arte possui uma significação autêntica e que, além da dimensão pública do falar - entendida como uma existência decaída da linguagem, genérica e anônima -, há uma fala não-coletiva, habitada pela autenticidade e pelo desvelamento do ser, é não levar em conta que esse modo de pensar abriga valores específicos e resulta, ele mesmo, de uma postura face à realidade - postura que, remetendo a condições humanas de existência, é, também ela, antropocêntrica de fio a pavio. Pretender limpar a arte de suas marcas antropológicoculturais mediante depurações verbais, para, aí então, conseguir apresentá-la em sua pureza originária é querer recuar a um ponto anterior à reflexão do pensamento crítico. $\mathrm{E}$ já não se trata de afirmar que o ser próprio e original não teria sido corretamente pensado, mas de assumir, ao contrário, que a dita verdade essencial, na indeterminação que a ontologia fundamental requer para si, seria impermeável a todos os sentidos. Como dirá o autor da Dialética negativa: "Os conceitos, instrumentos do pensamento humano, não podem ter nenhum sentido quando o próprio sentido é negado, quando toda memória de um sentido objetivo é expulsa para além dos mecanismos da formação conceitual". ${ }^{63}$ Isenta dos processos racionais habituais - considerados, por ela, como meros encobridores a serem eliminados -, a filosofia do ser pretende-se transcendente. E, ao ater-se a essa pretensão, julga-se inatacável.

Uma ontologia da arte que se coloca para além do processo de formação dos conceitos seria coercitiva, porque o fazer artístico, abismado num desdobramento inaugural destituído de todos os construtos usuais de pensamento, exigiria um esforço intensivo por esquecimento e pela suspensão dos antagonismos ínsitos ao ser-o-aí histórico gerando a ilusão de que estes últimos não mais existiriam. Projetando-se a partir de sua suposta essência, a obra de arte impõe-se como exposição da desocultação do ser e desonera-se de sua individualidade histórica - desresponsabilizando-se, nesse trilho, da totalidade sócio-política em que ela mesma se cristalizou. Se a tarefa de uma interpretação filosófica da arte não deve limitar-se a identificar as produções artísticas a seus respectivos conceitos, a obra, não obstante, como dirá Adorno, "desdobra-se em sua verdade por meio dessa identidade". ${ }^{64}$ Se não devemos vampirizar a arte por meio de corrosivas análises conceituais, nem por isso cumpre situá-la para além da aventura humana na história, excluindo ou suavizando as contradições teórico-especulativas que pudessem estorvar sua "pureza". Mas o projeto ontológico também poderia ser considerado coercitivo noutro sentido. Num apontamento intitulado "Jogo e estranheza do calendário histórico à luz da abissal história alemã", contido nos recém-publicados Cadernos negros, Heidegger elenca etapas daquilo que poderia ser caracterizado como um cronograma poético-salvífico:

1806: Hölderlin sai de cena e vem à tona uma antologia alemã; 1813: A arrancada alemã atinge seu ápice e nasce Richard Wagner; 1843: Hölderlin deixa o "mundo" e, um ano depois, Nietzsche vem à luz neste último; 1870/76: Inauguram-se os anos de industrialização alemã e são publicadas as 'Considerações extemporâneas' de 
Nietzsche; 1883: 'Zaratustra I' vem a lume e morre Richard Wagner; 1888: Fim de dezembro: 'euforia' de Nietzsche antes do colapso mental... (26.9.1889). ${ }^{65}$

Qual uma obra de arte orgânica e coletiva, a autêntica vida espiritual alemã teria nascido, sob tal ótica, a partir do solo da poesia de Hölderin; a partir daí, dar-se-ia a conhecer uma sucessão quase messiânica de autores: sob o influxo da obra poética de Hölderlin, bem como das obras Wagner e Nietzsche, seria possível detectar, como que numa corrente atada por proximidades de berço, um crescente renascimento do dizer essencial. O problema é que, não raro, Heidegger apresenta tal calendário - sobretudo no contexto atinente aos Cadernos negros - como um processo de incremento, como um ideal a ser alcançado na trajetória de uma clarificação mais e mais tonificante do ser. Tudo se passa como se ao homem moderno, autocomplacente com os instrumentos e armações que o aprisionam, não restasse outra saída senão aderir forçosamente ao inventário ontológico que cruza e constitui tal cronograma - fazendo ressurgir, digamos, sobre as ruínas carbonizadas da modernidade artística, as chamas de uma nova cultura. De teor escatológico, o quadro gera a impressão de que, não havendo outras alternativas, corremos o risco de perder um tesouro ontológico irrecuperável. Mais até. Tal ontologia poética também seria coercitiva para o próprio Heidegger. Pois, se pensarmos esse processo de expansão projetante do ser como um caminho rumo à projeção expansiva de si mesmo, o apelo lítero-apocalíptico heideggeriano implicaria o aceite de que apenas ao autor de Ser e tempo seria dado levar a vida espiritual ao seu elemento mais próprio - ainda que ele pudesse ecoar, ao longe, antecessores importantes. Os poetas e escritores do passado seriam empregados como testemunhas de um esquecimento do ser, de sorte que o pensador da Floresta Negra teria, por destinação, a tarefa de rechaçar as sombras que encobrem o ser na história de sua verdade. "O Dasein", dizia Heidegger, "existe em-vista-de um poder-se de si mesmo". ${ }^{60}$ Não poderíamos, quiçá, dizer a mesma coisa sobre o mencionado cronograma? E tanto mais sobre a ontologia da arte que dele decorre? Coagida, doravante, a existir em-vistade-si-mesma...

\footnotetext{
* Fernando Barros é professor adjunto do Departamento de Filosofia da UFC.

${ }^{1}$ WISSER, R. "Das Fernseh-Interview." In: Erinnerung an Martin Heidegger. Pfullingen: Günther Neske, 1977, p. 284.

${ }^{2}$ ADORNO. T. W. Dialética negativa. Tradução de Marco Antonio Casanova. Rio de Janeiro: Zahar, 2009, p.67.

${ }^{3}$ Idem. Ontologie und Dialektik. Frankfurt am Main: Suhrkamp, 2002, p. 127.

${ }^{4}$ HEIDEGGER, M. Ontologia: (hermenêutica da faticidade). Tradução de Renato Kirchner. Rio de Janeiro: Vozes, 2012, p. 9.

${ }^{5}$ Ibidem, p. 23.
} 
${ }^{6}$ Ibidem, p. 22.

7 Idem. Ser e tempo. Tradução e organização de Fausto Castilho. Campinas: Editora Unicamp; Petrópolis: Vozes, 2012, p. 57.

${ }^{8}$ ADORNO, T. W. Ontologie und Dialektik. Op. cit., p. 26.

${ }^{9}$ HEIDEGGER, M. Ser e tempo. Op. cit., p. 53.

${ }^{10}$ ADORNO, T. W. Ontologie und Dialektik. Op. cit., 2002, p. 30.

11 Ibidem, p. 30.

${ }^{12}$ HEIDEGGER, M. Ser e tempo. Op. cit., p. 49.

${ }^{13}$ Ibidem, p. 47.

${ }^{14}$ ADORNO, T. W. Ontologie und Dialektik. Op. cit., p. 31.

15 Ibidem, p. 36.

16 Ibidem, p. 32.

17 Ibidem, p. 60. É também nesse sentido que ganha relevo o lapidar comentário Gerd Borheim: "Heidegger não dá resposta à pergunta pelo ser, visto que toda resposta terminaria sendo uma determinação que traria consigo a entificação do ser" (BORNHEIM, G. Metafísica e finitude. São Paulo: Perspectiva, 2001. p. 198).

${ }^{18}$ HEIDEGGER, M. A origem da obra de arte. Tradução de Maria da Conceição Costa. Lisboa: Edições 70, 2008, p. 30.

19 Ibidem, p. 19.

20 Ibidem, p.19.

${ }^{21}$ Ibidem, p. 13.

22 Ibidem, p. 20.

${ }^{23}$ ARISTOTLE. Physics. Tradução de Robin Waterfield. Oxford: Oxford University, 1999, p. 52.

${ }^{24}$ Ibidem, p. 52.

${ }^{25}$ HEIDEGGER, M. A origem da obra de arte. Op. cit., p. 21.

${ }^{26}$ ARISTÓTELES. Ética a Nicômaco. In: Os Pensadores. Tradução de Leonel Vallandro e Gerd Bornheim. São Paulo: Abril Cultural, 1984, Livro I, 1094a, p. 49.

${ }^{27}$ HEIDEGGER, M. A origem da obra de arte. Op. cit., p. 67.

28 Ibidem, p. 31.

${ }^{29}$ Ibidem, p. 30.

${ }^{30}$ Ibidem, p. 47.

${ }^{31}$ Ibidem, p. 40.

${ }^{32}$ Idem. Ser e tempo. Op. cit., p. 47.

${ }^{33}$ Ibidem, p. 49.

${ }^{34}$ Idem. A origem da obra de arte. Op. cit., p. 24

${ }^{35}$ Cf. MAJETSCHAK, S. "Martin Heidegger". In: Klassiker der Kunstphilosophie. Von Platon bis Lyotard. Munique: Beck, 2005, p .228; cf. também SCHAPIRO, M. "The Still Life as a Personal Object. A Note on Heidegger and van Gogh. In: The Reach of Mind. Essays in memory of Kurt Goldstein. Nova York: Springer, 1968, p. 205. 
${ }^{36}$ HEIDEGGER, M. A origem da obra de arte. Op. cit., p. 25.

${ }^{37}$ Ibidem.

${ }^{38}$ Idem. "Observações sobre arte - escultura - espaço." Tradução de Alexandre de Oliveira Ferreira. In: Artefilosofia 5.. Ouro Preto, 2008, p. 19.

${ }^{39}$ Idem. A origem da obra de arte. Op. cit., p. 61.

${ }^{40}$ Ibidem, p. 59.

${ }^{41}$ Ibidem.

42 Ibidem, p. 60.

${ }^{43}$ Idem. Unterwegs zur Sprache. Pfulling: Neske, 1959, p. 32.

${ }^{44}$ Idem. Aus der Erfahrung des Denkens. In: Gesamtausgabe. Frankfurt am Main: Klostermann, 1983, v. 13, p. 181

${ }^{45}$ Idem. A origem da obra de arte. Op. cit., p. 19.

${ }^{46}$ Ibidem, p. 25.

47 KRAUSE, B. A grande orquestra da natureza. Tradução de Ivan Weisz Kuck. Rio de Janeiro: Zahar, 2013, p. 123.

${ }^{48}$ Em 1959, por ocasião do septuagésimo aniversário do filósofo alemão, a Academia de Artes de Berlim presenteou-o com um cassete contendo obras de Anton von Webern, o qual ele passou adiante, oferecendo-o ao colega musicólogo Marin Zenck . Cf., a respeito, VETTER, H. Grundriss Heidegger. Ein Lehrbuch zu Leben und Werk. Hamburg: Meiner, 2014, p. 215.

${ }^{49}$ HEIDEGGER, M. Nietzsche. Frankfurt am Main: Klostermann, 1996, GA 6.1, p. 87.

${ }_{50}$ ADORNO, T. W. Musikalische Schriften VI. In: Gesammelte Schriften. Frankfurt am Main: Suhrkamp, v. 19, 1984, p. 213.

${ }^{51}$ Idem. Filosofia da nova música. Tradução de Magda França. São Paulo: Perspectiva 2009, p. 36.

${ }^{52}$ Idem. Ontologie und Dialektik. Op. cit., p. 58.

${ }^{53}$ Ibidem, p. 59

54 Idem."Fragment über Musik und Sprache".In: Gesammelte Schriften. Band 16: Quasi una fantasia. Musikalische Schriften III. Frankfurt am Main: Suhrkamp, 1975, p. 251.

55 Ibidem., p. 251.

${ }^{56}$ Idem. Ästhetische Theorie. In: Gesammelte Schriften. Band 7. Frankfurt am Main: Suhrkamp, 1970, p. 72.

${ }^{57}$ Idwm."Fragment über Musik und Sprache". Op. cit., p. 252

58 Ibidem, p. 253

59 Ibidem, p. 251

${ }^{60}$ Ibidem.

${ }^{61}$ Ibidem, p. 252.

62 Ibidem.

${ }^{63}$ Idem. Dialética negativa. Tradução de Marco Antonio Casanova. Rio de Janeiro: Zahar, 2009, p. 81.

${ }^{64}$ Ibidem, p. 20. 
65 HEIDEGGER, M. Überlegungen II-VI (Schwarze Hefte 1931-1938). In: Gesamtausgabe. Frankfurt am Main: Klostermann, 2014, v. 94, p. 523.

${ }^{66}$ Idem. Ser e tempo. Op. cit., p. 989. 